\title{
An Experimental Study of Plastic Waste as Fine Aggregate Substitute for Environmentally Friendly Concrete
}

\author{
Anita Intan Nura Diana ${ }^{1, *}$, Subaidillah Fansuri ${ }^{1}$, Akhmad Feri Fatoni $^{2}$ \\ ${ }^{1}$ Department of Civil Engineering, Wiraraja University, Sumenep, Indonesia \\ ${ }^{2}$ Department of Nursing, Wiraraja University, Sumenep, Indonesia \\ Received 29 December 2020; received in revised form 06 April 2021; accepted 07 April 2021 \\ DOI: https://doi.org/10.46604/aiti.2021.6930
}

\begin{abstract}
Decomposing plastics, including plastic bottles, is a very difficult process because it takes 50-100 years. Every year, the use of plastic bottles is increasing, but only few people are willing to treat plastic bottle waste. In this study, plastic bottle waste is used as a substitute of fine aggregate and shaped in such a way to have a sand-like gradation. The variations of graded plastic bottle waste are $0 \%, 5 \%, 10 \%$, and $12 \%$. The test objects for each variation consist of three specimens. Data are analyzed by using regression and classical assumption test with SPSS program. The results of the data analysis show that there is a simultaneous effect on the compressive strength with variations in plastic waste substitution. The compressive strength decreases with the increase in the percentage of plastic added. Maximum compressive strength is at the variations of $0 \%$ and 5\% with19.192 MPa and 16.414 MPa, respectively.
\end{abstract}

Keywords: environmentally friendly concrete, plastic waste, compressive strength

\section{Introduction}

Plastic bottle waste is one of the most common environmental problems in this era. Plastic is a material that is difficult to decompose, taking up to 50-100 years. Every year, the amount of plastic bottle waste is increasing because people use plastic-based packaging almost every day. Nonetheless, people are less aware that behind the use of plastic materials, the recycling process of plastic bottle waste is not optimal. Some people recycle plastic bottle waste by converting them into vases, bags, and furniture so that it can be reused. However, the results of the survey conducted in Sumenep area regarding the recycling process of plastic bottle waste are still limited.

In the field of structure and materials, there have been many studies using plastic bottle waste as a research subject. Using plastic bottle waste as construction materials can reduce environmental damages caused by plastic waste pollution. In this study, plastic bottle waste is used as a substitute of fine aggregate and shaped in such a way so that its gradation is similar to the common fine aggregate, i.e. the sand.

Sand is the main ingredient for making concrete. The sand used in the concrete mixture is black sand, which is more suitable than other types of sand for building construction. The black sand content has a good binder with other concrete mixture materials. Behind the excellent use of black sand in building construction, a very serious problem arises. Land damage has often occurred due to uncontrolled mining of black sand (illegal mining) around the sand mining area. In the last few years, there have been conflicts that claimed the lives of environmentalists in the mining areas, including Lumajang area. Every day, black sand mining is carried out in the Lumajang area to meet consumer demand without any restrictions on black sand mining which will have a negative impact on the surrounding environment.

*Corresponding author. E-mail address: anita@wiraraja.ac.id

Tel.: +62-81332299841 
Sumenep does not have black sand materials for infrastructure purposes. The black sand in Sumenep Regency is imported from outside the city. Therefore, it is not surprising that the price of black sand in Sumenep Regency is quite high since the demand is high. As a result, people in Sumenep Regency have started many private companies and agencies that prioritize in building materials for fine aggregate using black sand.

Various studies have been carried out on utilizing plastic waste as a substitute of fine aggregate [1-11]. Guendouz et al. [1] investigated the use of two types of plastic scrap with the PET and LDPE logos used for the manufacture of fine aggregate in the form of powder in concrete z. Diana and Depriyanto [2] examined the effect of adding plastic fibers to paving blocks on compressive strength, shock resistance, and water absorption. Karimah [3] studied the compressive strength of normal strength concrete by adding 15\%,30\%, and 45\% LDPE plastic waste. Alvine [4] investigated the compressive strength of concrete by adding $20 \%, 40 \%$, and $60 \%$ ABS plastic waste.

Previous research combined plastic waste with other materials as a substitute for concrete mixtures. Among these materials are electronic plastic waste and marble dust on hardened properties of high-strength concrete [9] and plastic/rubber waste as environmentally friendly aggregates for concrete mixtures [10]. Adela, Behanu, and Gobena [11] utilized plastic waste as an alternative material for coarse aggregates. Several studies have shown that adding a number of plastic waste to the concrete mixture can reduce the quality of the concrete production [9-11]. Based on the previous research, further research on the use of plastic waste for concrete mixture is needed. Research can be in the form of variations in processing plastic waste and the addition of additives.

Table 1 Literature review

\begin{tabular}{|c|c|c|c|c|c|}
\hline Ref. & Plastic type & Shape & Replacement level & $\begin{array}{c}\text { Aggregate } \\
\text { replacement type }\end{array}$ & Application \\
\hline$[1]$ & PET + LDPE & Fibers and powder & $\begin{array}{c}\text { Powder: } 10 \%, 20 \%, 30 \%, \text { and } 40 \% \\
\text { Fibers: } 0.5 \%, 1 \%, 1.5 \%, \text { and } 2 \%\end{array}$ & Fine & Concrete \\
\hline$[2]$ & PET & Fibers & $0 \%, 0.25 \%, 0.50 \%, 0.75 \%$, and $1 \%$ & Coarse & $\begin{array}{c}\text { Paving } \\
\text { block }\end{array}$ \\
\hline$[3]$ & LDPE & Flakes & $15 \%, 30 \%$, and $45 \%$ & Coarse & Concrete \\
\hline$[4]$ & ABS & Flakes and powder & $20 \%, 40 \%$, and $60 \%$ & Coarse and fine & Concrete \\
\hline$[5]$ & E-plastic waste & Flakes & $0 \%, 5.5 \%, 11 \%$, and $16.5 \%$ & Coarse & Concrete \\
\hline$[6]$ & LDPE & Powder & particles below $75 \mu \mathrm{m}$ & Fine & Fine \\
\hline$[7]$ & LDPE & Shredded & $5 \%, 10 \%, 15 \%, 20 \%$, and $25 \%$ & Fine & Concrete \\
\hline$[8]$ & LDPE & Powder & $15 \%$ and $30 \%$ & Coarse and fine & Concrete \\
\hline$[9]$ & E-plastic waste & Irregular flakes & $0 \%, 10 \%, 20 \%, 30 \%$, and $40 \%$ & Coarse & Concrete \\
\hline$[11]$ & $\begin{array}{c}\text { Plastic bags and } \\
\text { plastic bottles }\end{array}$ & Irregular & $0 \%, 25 \%, 35 \%$, and $50 \%$ & & \\
\hline
\end{tabular}

Table 1 shows several types and shape of plastic waste that have been used in previous studies. Based on the background discussion above, only few researchers in Sumenep district utilized plastic waste as substitute of fine aggregate in concrete mixture. This study focuses on the use of graded plastic bottle waste (the plastic type is PET) as a substitute of fine aggregate, and uses the local coarse aggregates originating from Duko Village, Rubaru District, and Sumenep Regency based on the results of research conducted by Fansuri et.al [12]. The use of local materials is intended as a form of sustainability of construction materials by local construction actors in Sumenep Regency.

\section{Research Methodology}

\subsection{Flow chart of the study}

Fig. 1 shows the flow chart of the approach for this study. The process consists of five steps: problem statement, data collection, analysis data, result and discussion, and conclusions. The five steps are described as follows: 
Step 1: problem statement

The most important background is the plastic bottle waste problem that we face in this era. Plastic is a material that is difficult to decompose, which takes 50-100 years to decompose. Every year the amount of plastic bottle waste is increasing because almost every day people use plastic-based packaging. It takes innovation to turn plastic waste into construction materials (see introductory section for detailed explanations).

Step 2: data collection

Data are divided into primary data and secondary data. Primary data are collected through experiments in the Civil Engineering Laboratory by testing the aggregate materials for their density, water content, and sieve analysis, by making fresh concrete started with the calculation of mix design, manufacture of test object, slump test, concrete molding, and concrete curing, and by testing the compressive strength of fresh concrete. Secondary data are obtained by reviewing similar previous research and by testing the standards used in the study. The standards include the specific gravity test, water absorption of fine and coarse aggregates, fine aggregate and coarse aggregate sieve analysis testing, concrete manufacturing procedures, and concrete compressive strength testing.

Step 3: data analysis

Primary data are especially analyzed by using classical assumption tests (linearity test, normality test, and heteroscedasticity test) and linier regression. All the analyses in the study are executed by using SPSS software.

Step 4: result and discussion

At this stage, all the experimental and analytical results will be displayed in the form of tables, figures, and detailed calculations. Then, the obtained experimental results and analysis are compared with the previous literature.

Step 5: conclusion

At this stage, conclusions and recommendations will be obtained from the results of the experiments and analyses that have been carried out.

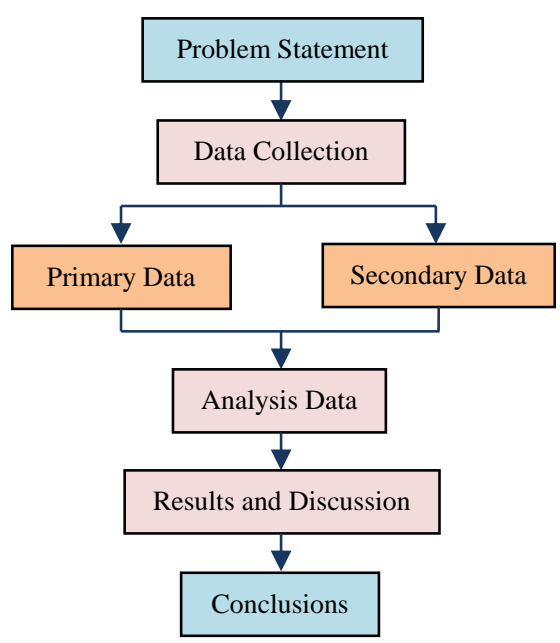

Fig. 1 Research methodology

\subsection{Model}

The model used in this study is fresh concrete with a mixture of plastic bottle waste. Plastic bottles are cut into small pieces to resemble grading sand. Furthermore, the small pieces of plastic waste used as a substitute for sand for the concrete mixture are divided into several variations. There are three concrete specimens as samples for each variation. The concrete compressive strength test is carried out for 14 days. Table 2 presents the test objects for each substitute variation. 
Table 2 Plastic gradient variation for each specimen

\begin{tabular}{|c|c|}
\hline Plastic gradient variations & Specimen for each variation \\
\hline $0 \%$ & 3 \\
\hline $5 \%$ & 3 \\
\hline $10 \%$ & 3 \\
\hline $12 \%$ & 3 \\
\hline Total samples & 12 \\
\hline
\end{tabular}

\subsection{Data analysis}

The data to be analyzed are obtained from the results of testing in the laboratory. Data from the laboratory are presented in tables and graphs. Data are analyzed using linear regression with classical assumption tests (linearity test, normality test, and heteroscedasticity test). All the analyses use SPSS program which are presented in the form of tables, pictures, and descriptions.

\section{Results and Discussion}

The results of this study consist of several test results for concrete mixtures (fine and coarse aggregate). After concrete compressive strength tests are carried out at the Civil Engineering Laboratory, compressive strength test data are analyzed using SPSS software. The results of the study are described below.

\subsection{Fine aggregate experiments}

There are several experiments carried out in the laboratory to determine the quality of fine aggregate, including water content experiment, specific gravity experiment [13], and sieve analysis experiment [14]. The following is the result of the water experiments in the laboratory.

Table 3 Data testing and calculation of fine aggregate water content

\begin{tabular}{|c|c|c|c|}
\hline Experiment & 1 & 2 & 3 \\
\hline Weight of original fine aggregate (W1) & $500 \mathrm{gr}$ & $500 \mathrm{gr}$ & $500 \mathrm{gr}$ \\
\hline Weight of oven-dry fine aggregate (W2) & $485 \mathrm{gr}$ & $487 \mathrm{gr}$ & $486 \mathrm{gr}$ \\
\hline Water content of fine aggregate (W1 - W2) / W2 $\times 100 \%$ & $3.52 \%$ & $2.67 \%$ & $2.88 \%$ \\
\hline Average of water content & \multicolumn{3}{|c|}{$3.023 \%$} \\
\hline
\end{tabular}

From the test shown in Table 3, it can be seen that the average value of fine aggregate water content is $3.023 \%$. The greater the difference between the original weight of the fine aggregate and the weight of the fine aggregate after being heated, the more water the aggregate will contain. From the test shown in Table 4, it can be seen that dry specific gravity is 2.56 , Saturated Surface Dry (SSD) is 2.62, apparent specific gravity is 2.71, and absorption is $2 \%$. Detailed calculations can be seen in Table 4.

Table 4 Data testing and calculation of fine aggregate density

\begin{tabular}{|c|c|c|c|c|}
\hline Experiment & 1 & 2 & 3 & Average \\
\hline Weight of pycno + SSD fine aggregate + water (W1) & 1005 & 1019 & 1017 & - \\
\hline Weight of SSD fine aggregate $(500$ gr) & 500 & 500 & 500 & - \\
\hline Weight of pycno + water $(\mathrm{W} 2)$ & 705 & 705 & 705 & - \\
\hline Weight of oven-dry fine aggregate $(\mathrm{W} 3)$ & 490 & 490 & 490 & - \\
\hline Dry specific gravity = W3 / (W2 + 500 - W1) & 2.45 & 2.63 & 2.60 & 2.56 \\
\hline SSD specific gravity = 500 / (W2 + 500 -W1) & 2.50 & 2.69 & 2.66 & 2.62 \\
\hline Apparent specific gravity = W3 / (W2 + W3 - W1) & 2.58 & 2.78 & 2.75 & 2.71 \\
\hline Absorption = [(500 - W3) / 500] $\times 100 \%$ & $2 \%$ & $2 \%$ & $2 \%$ & $2 \%$ \\
\hline
\end{tabular}


Figs. 2-5 illustrate the fine aggregate grading zone graphs. The value to illustrate the graph of the fine aggregate zone is obtained from Table 5. From the fine aggregate gradation graphs, it can be seen that the fine aggregate used is at the gradation limit no. 3. Furthermore, the amount of sand replaced by plastic bottle waste adjusts the selected gradation. It is done so that the plastic grading is similar to the sand grading used. The materials used in this study are shown in Fig. 6.

Table 5 Data testing and calculation of fine aggregate sieve analysis

\begin{tabular}{|c|c|c|c|c|c|}
\hline \multicolumn{2}{|c|}{ Filter size } & \multirow{2}{*}{$\begin{array}{c}\text { Restrained } \\
\text { weight }(\mathrm{gr})\end{array}$} & $\begin{array}{c}\text { Cumulative restrained } \\
\text { weight }(\mathrm{gr})\end{array}$ & $\begin{array}{c}\text { Cumulative } \\
\text { restrained }(\%)\end{array}$ & $\begin{array}{c}\text { Cumulative } \\
\text { passes }(\%)\end{array}$ \\
\hline 4.8 & $3 / 8$ & 30 & 30 & 3 & 96.95 \\
\hline 2.36 & 8 & 46 & 76 & 7.72 & 92.28 \\
\hline 1.70 & 12 & 60 & 136 & 13.81 & 86.19 \\
\hline 1.18 & 16 & 73 & 209 & 21.22 & 78.78 \\
\hline 0.60 & 30 & 210 & 419 & 42.54 & 57.46 \\
\hline 0.425 & 40 & 160 & 579 & 58.78 & 41.22 \\
\hline 0.30 & 50 & 42 & 621 & 63.05 & 36.95 \\
\hline 0.15 & 100 & 301 & 922 & 93.60 & 6.40 \\
\hline 0.075 & 200 & 48 & 970 & 98.48 & 1.52 \\
\hline \multicolumn{2}{|c|}{ Pan } & 15 & 985 & 100 & 0 \\
\hline \multicolumn{2}{|c|}{ Total } & 985 & \multicolumn{5}{l}{} \\
\hline
\end{tabular}

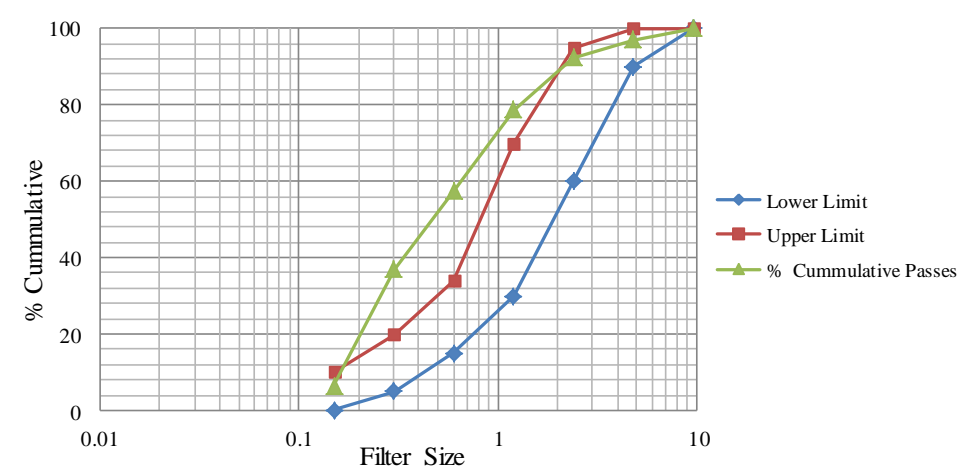

Fig. 2 Fine aggregate gradation limit no. 1

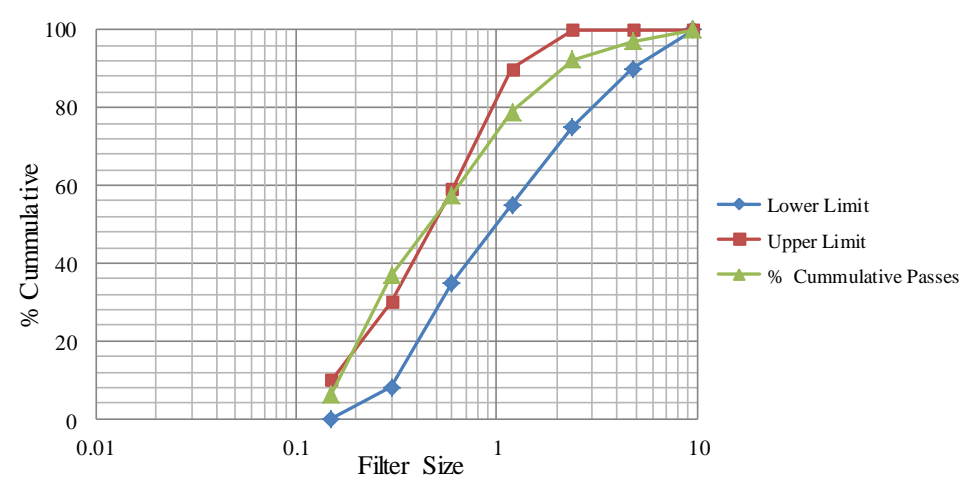

Fig. 3 Fine aggregate gradation limit no. 2

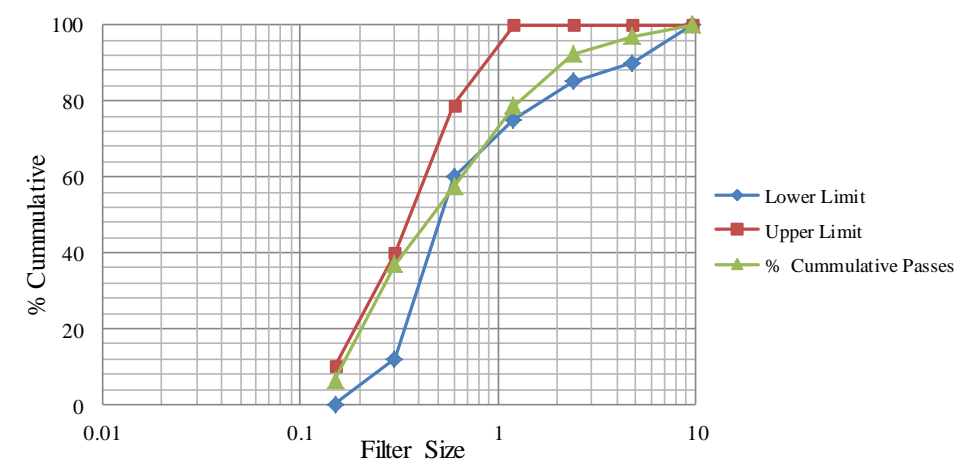

Fig. 4 Fine aggregate gradation limit no. 3 


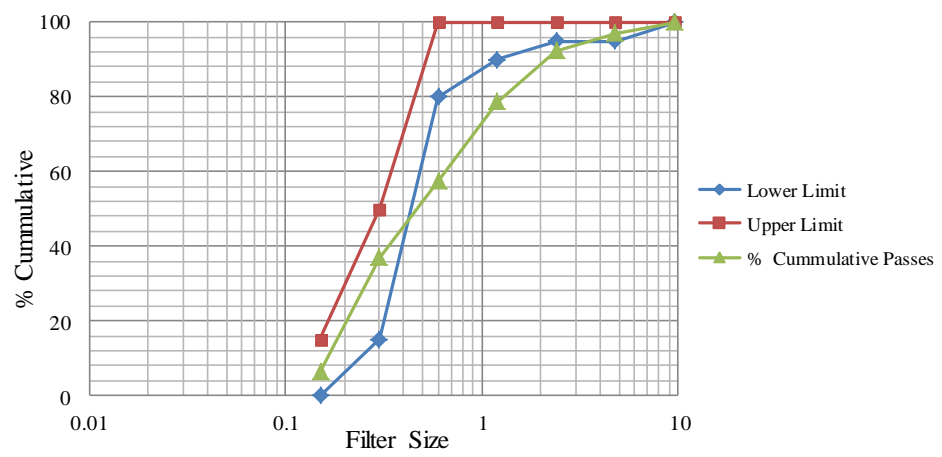

Fig. 5 Fine aggregate gradation limit no. 4

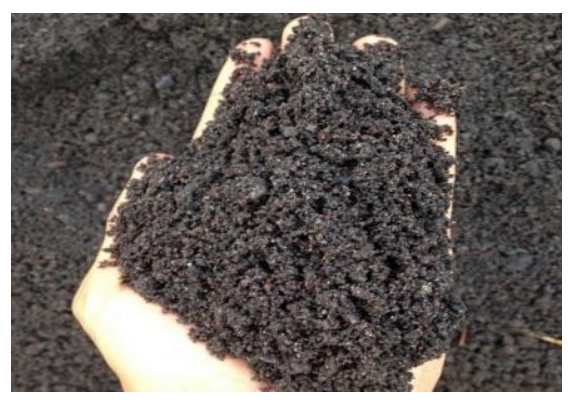

(a) Sand

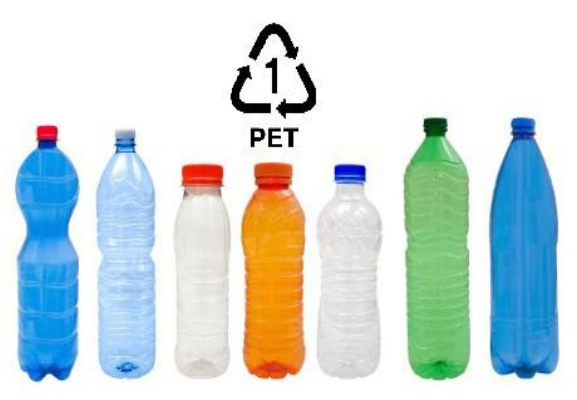

(b) Plastic bottle waste

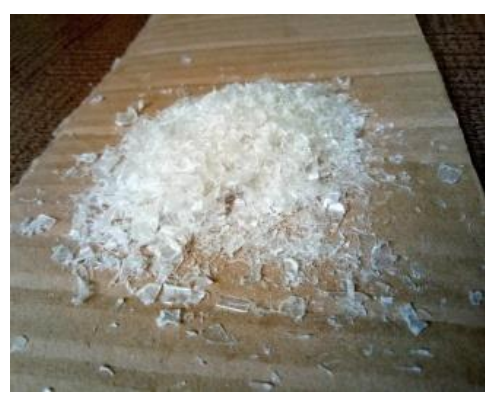

(c) Graded plastic

Fig. 6 Materials used in this study

\subsection{Coarse aggregate experiment}

There are several experiments conducted in the laboratory to determine the quality of the local coarse aggregate in Duko Village, Rubaru District [12]. The experiments include sieve analysis experiment [14] and water content experiment, specific gravity experiment [15]. The followings are the results of the experiments.

Table 6 Data testing and calculation of coarse aggregate water content

\begin{tabular}{|c|c|c|c|}
\hline Experiment & 1 & 2 & 3 \\
\hline Weight of original coarse aggregate (W1) & $500 \mathrm{gr}$ & $500 \mathrm{gr}$ & $500 \mathrm{gr}$ \\
\hline Weight of oven-dry coarse aggregate (W2) & $401 \mathrm{gr}$ & $401 \mathrm{gr}$ & $401 \mathrm{gr}$ \\
\hline Water content of coarse aggregate (W1 - W2) / W2 $\times 100 \%$ & $24.7 \%$ & $24.7 \%$ & $24.7 \%$ \\
\hline Average of water content & \multicolumn{3}{|c|}{$24.7 \%$} \\
\hline
\end{tabular}

From the test shown in Table 6 , it can be seen that the average of coarse aggregate water content value is $24.7 \%$. The greater the difference between the original weight of the fine aggregate and the weight of the fine aggregate after being heated, the more water the aggregate will contain. From the test shown in Table 7 below, it can be seen that the dry specific gravity is 2.02 , SSD specific gravity is 2.52 , apparent specific gravity is 4.03 , and absorption is $24.69 \%$.

Table 7 Data testing and calculation of coarse aggregate density

\begin{tabular}{|c|c|c|c|c|}
\hline Experiment & 1 & 2 & 3 & Average \\
\hline Weight of the test specimen in saturated surface dry condition (W1) & 500 & 500 & 500 & - \\
\hline Bucket weight in water (W2) & 631 & 631 & 631 & - \\
\hline Bucket weight + specimen in water (W3) & 930 & 935 & 932 & - \\
\hline Weight of oven-dry coarse aggregate (W4) & 401 & 401 & 401 & - \\
\hline Dry specific gravity = W4 / (W2 +W1 -W3) & 2.00 & 2.05 & 2.02 & 2.02 \\
\hline SSD specific gravity = W1 / (W2 +W1 -W3) & 2.49 & 2.55 & 2.51 & 2.52 \\
\hline Apparent specific gravity=W4 / (W2 +W4 -W3) & 3.93 & 4.13 & 4.01 & 4.03 \\
\hline Absorption = [(W1 $-\mathrm{W} 4) / \mathrm{W} 4] \times 100 \%$ & $24.69 \%$ & $24.69 \%$ & $24.69 \%$ & $24.69 \%$ \\
\hline
\end{tabular}


Figs. 7-9 illustrate the coarse aggregate grading zone graphs. The value to illustrate the graph of the coarse aggregate zone is obtained from Table 8. Based on the experimental results and gradation limit of coarse aggregate sieve analysis, it is obtained that the coarse aggregate gradation is in the coarse aggregate gradation with a maximum size of $40 \mathrm{~mm}$.

Table 8 Data testing and calculation of coarse aggregate sieve analysis

\begin{tabular}{|c|c|c|c|c|c|}
\hline \multicolumn{2}{|c|}{ Filter size } & Restrained & $\begin{array}{c}\text { Cumulative restrained } \\
\text { weight }(\mathrm{gr})\end{array}$ & $\begin{array}{c}\text { Cumulative } \\
\text { restrained }(\%)\end{array}$ & $\begin{array}{c}\text { Cumulative } \\
\text { passes }(\%)\end{array}$ \\
\cline { 1 - 3 } mm & inch & weight $(\mathrm{gr})$ & 0 & 0 & 100 \\
\hline 76.20 & 3 & 0 & 0 & 0 & 100 \\
\hline 50.8 & 2 & 0 & 0 & 0 & 100 \\
\hline 38.1 & 1.5 & 0 & 318 & 35.14 & 64.86 \\
\hline 25.40 & 1 & 318 & 553 & 61.10 & 38.90 \\
\hline 19 & $3 / 4$ & 235 & 623 & 68.84 & 31.16 \\
\hline 13.20 & $1 / 2$ & 70 & 733 & 80.99 & 19.01 \\
\hline 8.5 & $3 / 8$ & 110 & 893 & 98.67 & 1.33 \\
\hline 4.75 & $\# 4$ & 160 & 905 & 100 & 0 \\
\hline 2.36 & $\# 8$ & 12 & 905 & 100 & 0 \\
\hline 0.15 & 100 & 0 & 905 & 100 & 0 \\
\hline \multicolumn{2}{|c|}{ Pan } & 0 & 1000 & \multicolumn{5}{l}{} \\
\hline \multicolumn{2}{|c|}{ Total } & & 0 & - & \\
\hline
\end{tabular}

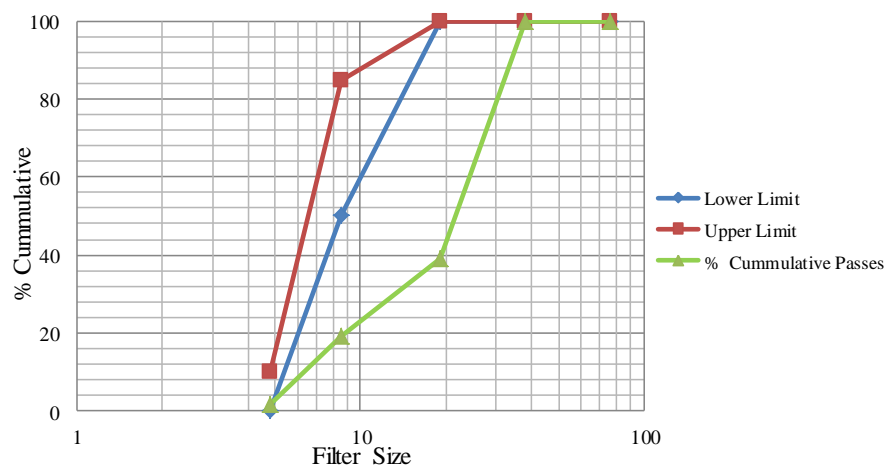

Fig. 7 Coarse aggregate gradation limit $(10 \mathrm{~mm})$

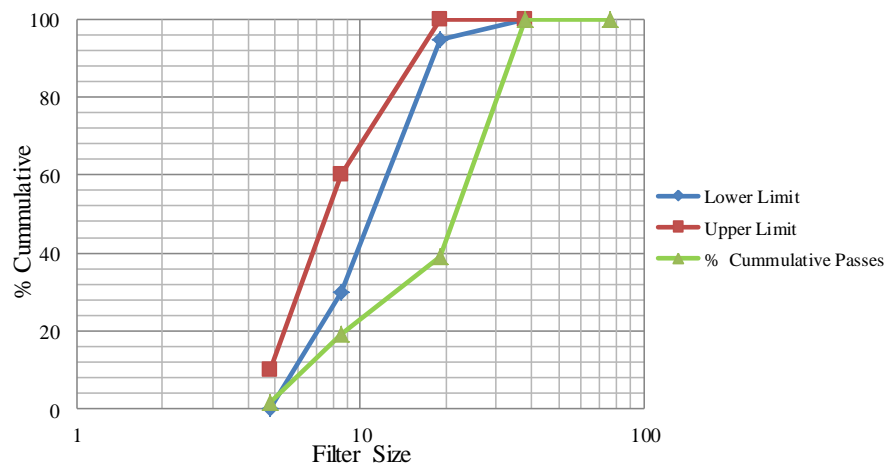

Fig. 8 Coarse aggregate gradation limit $(20 \mathrm{~mm})$

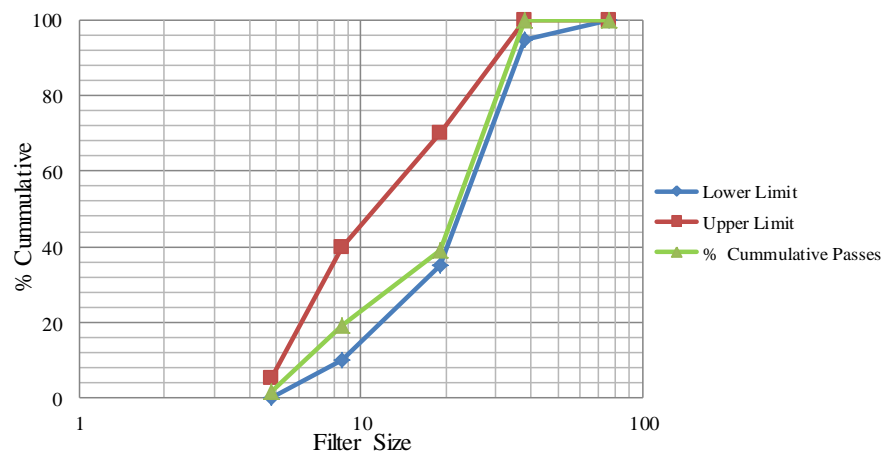

Fig. 9 Coarse aggregate gradation limit $(40 \mathrm{~mm})$ 


\subsection{Concrete mix design planning}

Mix design planning is an important stage in concrete planning. Based on the mix design planning, the composition of coarse aggregate, fine aggregate, cement, and water can be obtained. In this study, mix design planning uses the Indonesian National Standard (SNI) 03-2834 [16]. Data of concrete mixture material are used to create three specimens for each variation, providing the required compressive strength in $23 \mathrm{Mpa}$ equivalents to K270. Concrete mixture data for each variation is shown in Table 9.

Table 9 Data of concrete mixture material

\begin{tabular}{|c|c|c|c|c|c|}
\hline $\begin{array}{c}\text { Concrete mixture } \\
\text { material }\end{array}$ & $\begin{array}{c}\text { Variation 0\% } \\
(\mathrm{kg})\end{array}$ & $\begin{array}{c}\text { Variation 5\% } \\
(\mathrm{kg})\end{array}$ & $\begin{array}{c}\text { Variation 10\% } \\
(\mathrm{kg})\end{array}$ & $\begin{array}{c}\text { Variation 12\% } \\
(\mathrm{kg})\end{array}$ & Total $(\mathrm{kg})$ \\
\hline Cement & 3.43 & 3.43 & 3.43 & 3.43 & 13.72 \\
\hline Water & 2.035 & 2.035 & 2.035 & 2.035 & 8.14 \\
\hline Coarse aggregate & 12.571 & 12.571 & 12.571 & 12.571 & 50.284 \\
\hline Fine aggregate & 8.109 & 7.704 & 7.298 & 7.136 & 30.247 \\
\hline Plastic bottle waste & - & 0.405 & 0.811 & 0.973 & 2.189 \\
\hline
\end{tabular}

\subsection{Concrete slump testing}

In this study, the stages and calculations of concrete slump testing use the procedure listed in the Indonesian National Standard (SNI) 1972 [17]. Fig. 10 shows the tool used in the slum test, namely the abram cone. The test tool must be a mold made of a metal material that is not sticky and does not react with cement paste. The thickness of the metal shall not be less than $1.5 \mathrm{~mm}$, and when it is formed by a spinning process, there shall be no dots in the mold and its thickness is smaller than 1.15 $\mathrm{mm}$. The mold must be cone-shaped with a base diameter of $203 \mathrm{~mm}$, top diameter of $102 \mathrm{~mm}$, and height of $305 \mathrm{~mm}$. The base and top faces of the cone must be open and parallel to each other and perpendicular to the axis of the cone. The mold must be equipped with a treadle section and a handle as shown in Fig. 10.

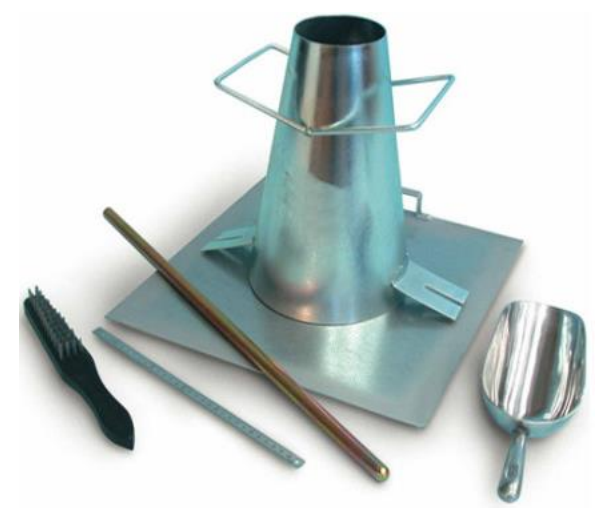

Fig. 10 Mold for slump test (abram cone)

Table 10 Data testing and calculation of slump value

\begin{tabular}{|c|c|c|c|c|c|c|}
\hline \multirow{2}{*}{$\begin{array}{c}\text { Plastic waste } \\
\text { variation }\end{array}$} & \multirow{2}{*}{$\begin{array}{c}\text { Mold of slump test } \\
\text { height }(\mathrm{cm})\end{array}$} & \multicolumn{2}{|c|}{$\begin{array}{c}\text { Height of each } \\
\text { specimen }(\mathrm{cm})\end{array}$} & \multicolumn{2}{c|}{$\begin{array}{c}\text { Slump value for } \\
\text { each specimen }(\mathrm{cm})\end{array}$} & \multirow{2}{*}{$\begin{array}{c}\text { Average } \\
(\mathrm{cm})\end{array}$} \\
\cline { 3 - 6 } & & 1 & 2 & 1 & 2 & \\
\hline $0 \%$ & 30 & 19 & 21 & 11 & 9 & 10 \\
\hline $5 \%$ & 30 & 21 & 21 & 9 & 9 & 9 \\
\hline $10 \%$ & 30 & 20 & 22 & 10 & 8 & 9 \\
\hline $12 \%$ & 30 & 22 & 21 & 8 & 9 & 8.5 \\
\hline
\end{tabular}

Based on Table 10, which shows the slump plan set in $60-180 \mathrm{~mm}$, the results of the laboratory experiments meet the requirements. The lowest average value of the slump test is $85 \mathrm{~mm}$ and the highest value is $100 \mathrm{~mm}$. This value is within the planned slump value. 


\subsection{Concrete compressive strength}

This concrete compressive strength test is carried out according to the procedure in the Indonesian National Standard (SNI) 1974 [18]. The detailed results of the concrete compressive strength test can be seen in Tables 11-14.

Table 11 Data testing and calculation of concrete compressive strength value in $0 \%$ variation

\begin{tabular}{|c|c|c|c|c|c|c|c|c|}
\hline \multirow{2}{*}{ Sample } & \multicolumn{2}{|c|}{ Date } & \multirow{2}{*}{$\begin{array}{c}\text { Weight } \\
(\mathrm{kg})\end{array}$} & \multirow{2}{*}{$\mathrm{P}(\mathrm{N})$} & \multirow{2}{*}{$\mathrm{A}\left(\mathrm{mm}^{2}\right)$} & \multirow{2}{*}{$\begin{array}{c}\text { Age } \\
\text { conversion } \\
\text { (14 days) }\end{array}$} & \multirow{2}{*}{$\begin{array}{c}\text { Compressive } \\
\text { strength (f'c) } \\
\mathrm{MPa}\end{array}$} & \multirow{2}{*}{$\begin{array}{c}\text { Characteristic } \\
\text { concrete }(\mathrm{K}) \\
\mathrm{kg} / \mathrm{cm}^{2}\end{array}$} \\
\hline & Create & Test & & & & & & \\
\hline 1 & $06 / 05 / 2020$ & $20 / 05 / 2020$ & 8.143 & 340000 & 22500 & 0.88 & 17.172 & 206.888 \\
\hline 2 & $06 / 05 / 2020$ & $20 / 05 / 2020$ & 8.064 & 395000 & 22500 & 0.88 & 19.949 & 240.355 \\
\hline 3 & $06 / 05 / 2020$ & $20 / 05 / 2020$ & 8.083 & 405000 & 22500 & 0.88 & 20.455 & 246.440 \\
\hline \multicolumn{7}{|c|}{ Average of variation: $0 \%$} & 19.192 & 231.228 \\
\hline
\end{tabular}

Table 12 Data testing and calculation of concrete compressive strength value in $5 \%$ variation

\begin{tabular}{|c|c|c|c|c|c|c|c|c|}
\hline \multirow{2}{*}{ Sample } & \multicolumn{2}{|c|}{ Date } & \multirow{2}{*}{$\begin{array}{c}\text { Weight } \\
(\mathrm{kg})\end{array}$} & \multirow{2}{*}{$\mathrm{P}(\mathrm{N})$} & \multirow{2}{*}{$\mathrm{A}\left(\mathrm{mm}^{2}\right)$} & \multirow{2}{*}{$\begin{array}{c}\text { Age } \\
\text { conversion } \\
\text { (14 days) }\end{array}$} & \multirow{2}{*}{$\begin{array}{c}\text { Compressive } \\
\text { strength (f'c) } \\
\mathrm{MPa}\end{array}$} & \multirow{2}{*}{$\begin{array}{c}\text { Characteristic } \\
\text { concrete }(\mathrm{K}) \\
\mathrm{kg} / \mathrm{cm}^{2}\end{array}$} \\
\hline & Create & Test & & & & & & \\
\hline 1 & $12 / 05 / 2020$ & $26 / 05 / 2020$ & 7.926 & 410000 & 22500 & 0.88 & 20.707 & 249.483 \\
\hline 2 & $12 / 05 / 2020$ & $26 / 05 / 2020$ & 7.615 & 360000 & 22500 & 0.88 & 18.182 & 219.058 \\
\hline 3 & $12 / 05 / 2020$ & $26 / 05 / 2020$ & 8.058 & 205000 & 22500 & 0.88 & 10.354 & 124.741 \\
\hline \multicolumn{7}{|c|}{ Average of variation: $5 \%$} & 16.414 & 197.761 \\
\hline
\end{tabular}

Table 13 Data testing and calculation of concrete compressive strength value in $10 \%$ variation

\begin{tabular}{|c|c|c|c|c|c|c|c|c|}
\hline \multirow{2}{*}{ Sample } & \multicolumn{2}{|c|}{ Date } & \multirow{2}{*}{$\begin{array}{c}\text { Weight } \\
(\mathrm{kg})\end{array}$} & \multirow{2}{*}{$\mathrm{P}(\mathrm{N})$} & \multirow{2}{*}{$\mathrm{A}\left(\mathrm{mm}^{2}\right)$} & \multirow{2}{*}{$\begin{array}{c}\text { Age } \\
\text { conversion } \\
\text { (14 days) }\end{array}$} & \multirow{2}{*}{$\begin{array}{c}\text { Compressive } \\
\text { strength (f'c) } \\
\mathrm{MPa}\end{array}$} & \multirow{2}{*}{$\begin{array}{c}\text { Characteristic } \\
\text { concrete }(\mathrm{K}) \\
\mathrm{kg} / \mathrm{cm}^{2}\end{array}$} \\
\hline & Create & Test & & & & & & \\
\hline 1 & $18 / 05 / 2020$ & $01 / 06 / 2020$ & 7.240 & 240000 & 22500 & 0.88 & 12.121 & 146.039 \\
\hline 2 & $18 / 05 / 2020$ & $01 / 06 / 2020$ & 7.200 & 185000 & 22500 & 0.88 & 9.343 & 112.571 \\
\hline 3 & $18 / 05 / 2020$ & $01 / 06 / 2020$ & 7.160 & 200000 & 22500 & 0.88 & 10.101 & 121.699 \\
\hline \multicolumn{7}{|c|}{ Average of variation: $10 \%$} & 10.522 & 126.770 \\
\hline
\end{tabular}

Table 14 Data testing and calculation of concrete compressive strength value in $12 \%$ variation

\begin{tabular}{|c|c|c|c|c|c|c|c|c|}
\hline \multirow{2}{*}{ Sample } & \multicolumn{2}{|c|}{ Date } & \multirow{2}{*}{$\begin{array}{c}\text { Weight } \\
(\mathrm{kg})\end{array}$} & \multirow{2}{*}{$\mathrm{P}(\mathrm{N})$} & \multirow{2}{*}{$\mathrm{A}\left(\mathrm{mm}^{2}\right)$} & \multirow{2}{*}{$\begin{array}{l}\text { Age } \\
\text { conversion } \\
\text { (14 days) }\end{array}$} & \multirow{2}{*}{$\begin{array}{c}\text { Compressive } \\
\text { strength (f'c) } \\
\mathrm{MPa}\end{array}$} & \multirow{2}{*}{$\begin{array}{c}\text { Characteristic } \\
\text { concrete }(\mathrm{K}) \\
\mathrm{kg} / \mathrm{cm}^{2}\end{array}$} \\
\hline & Create & Test & & & & & & \\
\hline 1 & $18 / 05 / 2020$ & $01 / 06 / 2020$ & 7.284 & 215000 & 22500 & 0.88 & 10.859 & 130.826 \\
\hline 2 & $18 / 05 / 2020$ & $01 / 06 / 2020$ & 7.140 & 210000 & 22500 & 0.88 & 10.606 & 127.784 \\
\hline 3 & $18 / 05 / 2020$ & $01 / 06 / 2020$ & 7.247 & 200000 & 22500 & 0.88 & 10.101 & 121.699 \\
\hline \multicolumn{7}{|c|}{ Average of variation: $12 \%$} & 10.522 & 126.770 \\
\hline
\end{tabular}

Fig. 11 shows the relationship between the variations of plastic waste substitution in the fine aggregate of concrete mixture and the result of compressive strength value. The highest compressive strength is shown by concrete without plastic waste substitution in the concrete mixture (19.19 MPa in $0 \%$ variation). There is a decrease in compressive strength that is in line with the increase in the amount of plastic waste added to the concrete mixture. All the results of the compressive strength of the concrete, none of them meets the compressive strength requirements in $23 \mathrm{MPa}$.

There are several factors that cause failure to pass in this experiment. First, the coarse aggregate material used do not meet the overall SNI requirements. The aggregate material in this study uses the local aggregate in Sumenep area. In a study conducted by Fansuri et al. [12] in five local coarse aggregate mining locations, namely Batuan village, Batu Putih village, Dasuk village, Duko village, and Ellak Daya village, it can be seen that the aggregate in Duko village met the parameters of coarse aggregate as a concrete material, where the water absorption was $1.83 \%$ (maximum value is $3 \%$ ), specific gravity was 
2.57 (minimum value is 1.8), test value wear and tear using Los Angeles was 24.8\% (maximum value is $40 \%$ ), and volume weight was $2075.5 \mathrm{~kg} / \mathrm{m}^{3}$ (minimum value is $2200 \mathrm{~kg} / \mathrm{m}^{3}$ ). Second, several studies that have been done previously explained that the use of additives in the form of additives (chemical compounds) is needed as the liquid can add strength to concrete with variations of plastic waste. Meanwhile, the experiments conducted in this study do not use added materials in the form of additives (chemical compounds).

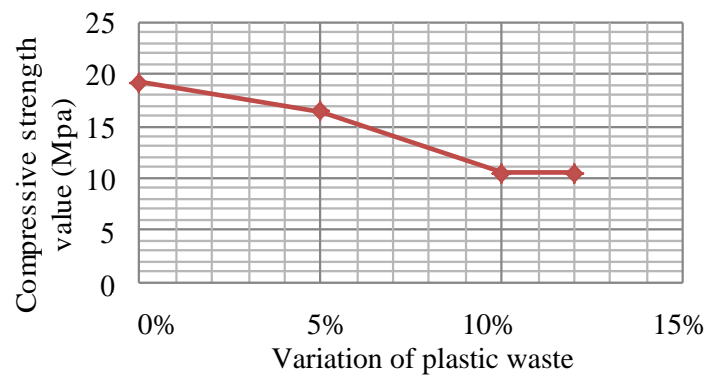

Fig. 11 Compressive strength relationship and plastic waste variations

\subsection{Normality test of concrete}

Normality test in this study uses the SPSS for windows program. The normality test is used to determine whether the obtained research data has a normal distribution or not. From Table 15, it can be seen that the spread of unstandardized residual value is normal because the significant value is $0.200>0.05$ (normally distributed). Therefore, this analysis can be processed to regression analysis because the conditions in the classical assumption test, in this case the residual value, have been stated as normally distributed.

Table 15 Normality test result of unstandardized residual using one-sample Kolmogorov-Smirnov test

\begin{tabular}{|l|c|c|}
\hline \multicolumn{2}{|c|}{$\mathrm{N}$} & 12 \\
\hline \multirow{2}{*}{ Normal parameters $^{\mathrm{a}, \mathrm{b}}$} & Mean & 0.0000000 \\
\cline { 2 - 3 } & Std. deviation & 31.61054075 \\
\hline \multirow{2}{*}{ Most extreme differences } & Absolute & 0.194 \\
\cline { 2 - 3 } & Positive & 0.194 \\
\cline { 2 - 3 } Test statistic & Negative & -0.183 \\
\hline \multicolumn{2}{|c|}{ Asymp. sig. (2-tailed) } & 0.194 \\
\hline a. Normal test distribution \\
\hline b. Calculated from data \\
\hline c. Lilliefors significance correction \\
\hline d. Lower bound of the true significance \\
\hline
\end{tabular}

\subsection{Heteroscedasticity test of concrete}

This test is used to determine deviation of the classic assumptions of heteroscedasticity because there is an inequality of variance from one residual observation to another, while in the regression model, it is actually expected to be constant. In this test, the researchers use the SPSS 25 for windows program and the Glejtser method.

The symptom of heteroscedasticity is shown by the regression coefficient of the independent variable on the absolute value of the residual. In decision making, there is no symptom of heteroscedasticity if the probability value is greater than the alpha value (0.05). From Table 16, it can be concluded that heteroscedasticity do not occur in the regression model because the sig. variation of plastic waste to the absolute residual is $0.386>0.05$. 
Table 16 Result of heteroscedasticity test of concrete

\begin{tabular}{|l|c|c|c|c|c|c|}
\hline \multirow{2}{*}{ Model } & \multicolumn{2}{|c|}{ Unstandardized coefficient } & $\begin{array}{c}\text { Standardized } \\
\text { coefficient }\end{array}$ & \multirow{2}{*}{ T } & \multirow{2}{*}{ Sig. } \\
\cline { 3 - 6 } & B & Std. error & Beta & & \\
\hline \multirow{2}{*}{1} & Constant & 30.647 & 10.761 & - & 2.848 & 0.017 \\
\cline { 2 - 7 } & Plastic waste variation & -1.189 & 1.312 & -0.275 & -0.906 & 0.386 \\
\hline \multicolumn{2}{|l|}{ a. Dependent variable: RE3 3}
\end{tabular}

\subsection{Hypotheses test and regression equations}

There are two variables in this study, namely independent variable (X) and dependent variable (Y). Variable $\mathrm{X}$ is variation of plastic waste, and variable $\mathrm{Y}$ is concrete compressive strength. The hypotheses in this study are as follows.

(1) Ho: There is no simultaneous effect between variable $\mathrm{X}$ on variable $\mathrm{Y}$.

(2) Ha: There is a simultaneous effect between variable $\mathrm{X}$ on variable $\mathrm{Y}$.

Table 17 ANOVA test result

\begin{tabular}{|c|c|c|c|c|c|c|}
\hline \multicolumn{7}{|c|}{ ANOVA $^{\mathrm{a}}$} \\
\hline & Model & Sum of squares & Df & Mean square & $\mathrm{F}$ & Sig. \\
\hline \multirow{3}{*}{1} & Regression & 23784.941 & 1 & 23784.941 & 21.639 & $0.001^{\mathrm{b}}$ \\
\hline & Residual & 10991.489 & 10 & 1099.149 & - & - \\
\hline & Total & 34776.430 & 11 & - & - & - \\
\hline \multicolumn{7}{|c|}{ a. Dependent variable: Compressive strength } \\
\hline \multicolumn{7}{|c|}{ b. Predictors: Constant, Plastic waste variation } \\
\hline
\end{tabular}

Hypotheses test can be done using the F test and significance test (probability). The test rule is to use the F test under several conditions: if $\mathrm{F}$ value $\leq \mathrm{F}$ table, Ho is accepted; if $\mathrm{F}$ value $>\mathrm{F}$ table, Ho is rejected. Based on the calculation, the $\mathrm{F}$ value of the ANOVA table is 21.639 and the F table value is 4.96. Thus, it can be concluded that F value > F table. It means Ho is rejected, or in other words, $\mathrm{Ha}$ is accepted (there is simultaneous effect between variable $\mathrm{X}$ on variable $\mathrm{Y}$ ).

The significance test (probability) is conducted under several conditions: if probability (sig.) $>\alpha$, Ho is accepted; if probability (sig.) $<\alpha$, Ho is rejected. Based on Table 17, the probability value (sig.) $=0.001$ and the significant level value $\alpha=$ 0.05. Therefore, it can be concluded that the probability value (sig.) $<\alpha$. It means Ho is rejected, or in other words, Ha is accepted (there is a simultaneous effect between variable $\mathrm{X}$ on variable $\mathrm{Y}$ ).

Table 18 Coefficient results of compressive strength regression analysis

\begin{tabular}{|c|c|c|c|c|c|c|c|c|}
\hline \multicolumn{9}{|c|}{ Coefficient $^{\mathrm{a}}$} \\
\hline & \multirow{2}{*}{ Model } & \multicolumn{2}{|c|}{$\begin{array}{l}\text { Unstandardized } \\
\text { coefficients }\end{array}$} & \multirow{2}{*}{$\begin{array}{c}\begin{array}{c}\text { Standardized } \\
\text { coefficients }\end{array} \\
\text { Beta }\end{array}$} & \multirow{2}{*}{$\mathrm{T}$} & \multirow{2}{*}{ Sig. } & \multicolumn{2}{|c|}{$95 \%$ Confidence interval for B } \\
\hline & & B & Std. error & & & & Lower bound & Upper bound \\
\hline \multirow{2}{*}{1} & Constant & 235.162 & 16.853 & - & 13.954 & 0.000 & 197.611 & 272.713 \\
\hline & Plastic waste variation & -9.560 & 2.055 & -0.827 & -4.652 & 0.001 & -14.139 & -4.981 \\
\hline
\end{tabular}

Based on Table 18, it can be analyzed that the regression equation model for the simultaneous effect on compressive strength with plastic waste variation is $\mathrm{Y}=235.162-9.560 \mathrm{X}$, compressive strength without the addition of variation of plastic bottle waste is $\mathrm{X}=0$, and the value of compressive strength is $(\mathrm{Y})=235.162 \mathrm{~kg} / \mathrm{cm}^{2}(19.518 \mathrm{MPa})$. If the addition of variation of plastic bottle waste is $\mathrm{X}=1 \%$, it is estimated that the value of compressive strength $(\mathrm{Y})=235.162-9.560(1)=225.602$ $\mathrm{kg} / \mathrm{cm}^{2}(18.725 \mathrm{MPa})$ is added. Every $1 \%$ addition of plastic bottle waste will decrease the compressive strength of the concrete by $9.560 \mathrm{~kg} / \mathrm{cm}^{2}(0.793 \mathrm{MPa})$. 


\section{Conclusions}

Based on the results of the analysis and discussion in the previous section, the following conclusions are obtained.

(1) The linear regression equation for the variation of plastic waste on the compressive strength of concrete is $\mathrm{Y}=235.162-$ $9.560 \mathrm{X}$, meaning that there is a significant influence between the variation of plastic waste on the compressive strength of concrete.

(2) The more plastic waste added into the variation, the lower the concrete compressive strength, where the maximum compressive strength is at the variations of $0 \%$ and $5 \%$, namely $19.192 \mathrm{MPa}$ for the variation of $0 \%$ and $16.414 \mathrm{MPa}$ for the variation of $5 \%$. In general, the concrete which contains more plastic has poorer durability performance.

\section{Conflicts of Interest}

The authors declare no conflict of interest.

\section{References}

[1] M. Guendouz, F. Debieb, O. Boukendakdji, E. H. Kadri, M. Bentchikou, and H. Soualhi, "Use of Plastic Waste in Sand Concrete," Journal of Materials and Environmental Science, vol. 7, no. 2, pp. 382-389, October 2016.

[2] A. I. N. Diana and H. Depriyanto, "The Effect of Using Economic Plastic Fiber (Eco Plafie) Paving Block on Compressive Strength, Shock Resistance, and Water Absorption as Environmentally Friendly Products," National Conference on Mathematics, Science and Education, Madura Islamic University Press, October 2018, pp. 19-26.

[3] H. Karimah, "Experimental Study of the Effect of LDPE Cast Plastic Content on the Compressive Strength of Normal Strength Concrete," Thesis, Department Civil Engineering, Parahyangan Catholic University, Bandung, Jawa Barat, 2018.

[4] Alvine, "Experimental Study of the Effect of ABS Plastic Waste as a Partial Substitution of Concrete Aggregates with a Design Compressive Strength of F'c = $35 \mathrm{MPa}$," Thesis, Department Civil Engineering, Parahyangan Catholic University, Bandung, Jawa Barat, 2019.

[5] S. Suleman and S. Needhidasan, "Utilization of Manufactured Sand as Fine Aggregates in Electronic Plastic Waste Concrete of M30 Mix," Materials Today, vol. 33, no. 1, pp. 1192-1197, September 2020.

[6] B. V. Bahoria, D. K. Parbat, and P. B. Nagarnaik, "XRD Analysis of Natural Sand, Quarry Dust, Waste Plastic (LDPE) to be Used as a Fine Aggregate in Concrete," Materials Today, vol. 5, no.1, pp. 1432-1438, February 2018.

[7] S. S. Mathi, V. Johnpaul, R. Sindhu, P. R. Riyas, and N. Chidambaram, "Mechanical Properties of Concrete with Plastic as Partial Replacement of Fine Aggregate," Materials Today: Proceedings, in press.

[8] Z. C. Steyn, A. J. Babafemi, H. Fataar, and R. Combrinck, "Concrete Containing Waste Recycled Glass, Plastic, and Rubber as Sand Replacement," Construction and Building Materials, vol. 269, 121242, February 2021.

[9] A. Evram, T. Akçaoğlu, K. Ramyar, and B. Çubukçuoğlu, "Effects of Waste Electronic Plastic and Marble Dust on Hardened Properties of High Strength Concrete," Construction and Building Materials, vol. 263, no. 1, pp. 1-10, September 2020.

[10] X. Li, T. C. Ling, and K. H. Mo, "Functions and Impacts of Plastic/Rubber Wastes as Eco-Friendly Aggregate in Concrete-A Review," Construction and Building Materials, vol. 240, no. 1, pp. 1-13, December 2019.

[11] Y. Adela, M. Behanu, and B. Gobena, "Plastic Wastes as a Raw Material in the Concrete Mix: An Alternative Approach to Manage Plastic Wastes in Developing Countries," International Journal of Waste Resources, vol. 10, no. 382, pp. 1-7, June 2020.

[12] S. Fansuri and A. I. N. Diana, "Characteristics of Coarse Aggregate and Fine Aggregate for Building Materials in Sumenep Regency," National Conference on Mathematics, Science, and Education, Madura Islamic University Press, October 2018, pp. 9-18.

[13] Method of Test for Specific Gravity and Water Absorption of Fine Aggregate, Indonesian National Standard 1970, 2008.

[14] Test Method for Fine Aggregate and Coarse Aggregate Sieve Analysis, Indonesian National Standard ASTM C136, 2012.

[15] Method of Test for Specific Gravity and Water Absorption of Coarse Aggregate, Indonesian National Standard 1969, 2008.

[16] Procedure for Making a Normal Concrete Mix Plan, Indonesian National Standard 03-2834, 2000.

[17] How to Test a Concrete Slump, Indonesian National Standard 1972, 2008.

[18] How to Test Concrete Compressive Strength with Cylindrical Test Objects, Indonesian National Standard $1974,2011$. 